\title{
THE AdJUdicATION OF MIRACLES: RETHINKING THE CRITERIA OF HISTORICITY
}

\author{
Authors: \\ Michael R. Licona ${ }^{1}$ \\ Jan G. van der Watt ${ }^{1}$

\begin{abstract}
Affiliations:
${ }^{1}$ Department of New

Testament Studies,

University of Pretoria,

South Africa
\end{abstract}

\section{Correspondence to:}

Michael R. Licona

e-mail:

mike@risenjesus.com

\section{Postal address:}

PO Box 39, Alpharetta, GA

30009, 404.921.4618, USA

\section{Keywords:}

miracles; principle of

analogy; antecedent probability; historicity of miracle stories; Biblical hermeneutics

\section{Dates:}

Received: 25 Mar. 2008

Accepted: 27 Nov. 2008

Published: 22 June 2009

How to cite this article: Licona, M.R. \& Van der Watt, J.G., 2009, 'The adjudication of miracles: Rethinking the criteria of historicity', HTS Teologiese Studies/Theological Studies 65(1), Art. \#130, 7 pages.

DOI: 10.4102/hts.v65i1.130

\section{This article is available}

at:

http://www.hts.org.za

\section{Note:}

This article is a reworked version of Dr Michael R. Licona's (Alpharetta, GA, USA), PhD thesis in New Testament Studies, titled 'The historicity of the resurrection of Jesus: Historiographical considerations in the light of recent debates', submitted to and accepted by the Faculty of Theology at the University of Pretoria, under supervision of Prof. Dr Jan G. van der Watt.

\section{(c) 2009. The Authors.} Licensee: OpenJournals Publishing. This work is licensed under the Creative Commons Attribution License.

\section{ABSTRACT}

This is the second article in a series of two that discusses whether historians are within their professional rights to investigate miracle claims. In the first, I made a positive case that they are and then proceeded to examine two major arguments in support of a negative verdict to the issue: the principle of analogy and antecedent probability. I argued that neither should deter historians from issuing a positive verdict on miracle claims when certain criteria are met and the event is the best explanation of the relevant historical bedrock. In this second article, I examine three additional objections commonly appealed to by biblical scholars: the theological objection, lack of consensus and miracle claims in multiple religions. The resurrection of Jesus is occasionally cited as an example.

\section{INTRODUCTION}

The question as to whether historians are within their professional rights when adjudicating on the historicity of miracle claims is a discussion taking place even outside of the community of biblical scholars (Licona 2009). In my previous article, I also made a positive case that historians are within their professional rights to adjudicate on the historicity of miracle claims. I defined miracle as an event in history for which natural explanations are inadequate and proposed that we may identify a miracle when the event (a) is highly unlikely to have occurred, given the circumstances and/or natural law and (b) occurred in an environment or context charged with religious significance. When these criteria are met and the reported event is the best explanation of the relevant historical bedrock, the historian is warranted in affirming that a miracle has occurred. I then proceeded to examine two major arguments in support of a negative verdict to the issue: the principle of analogy and antecedent probability. I argued that neither should deter historians from issuing a positive verdict on miracle claims when the above criteria are met and the event is the best explanation of the relevant historical bedrock. In this second article, I will examine three additional common objections to historians adjudicating on miracle claims: the theological objection, lack of consensus and miracle claims in multiple religions.

\section{THEOLOGICAL OBJECTIONS}

John Meier contends that although modern scholars are rational to believe in miracles, professional historians cannot assign a judgement of 'historical' to a miracle claim.

[I]t is inherently impossible for historians working with empirical evidence within the confines of their own discipline ever to make the positive judgment: "God has directly acted here to accomplish something beyond all human power." The very wording of this statement is theo-logical ("God has directly acted ..."). What evidence and criteria could justify a historian as a historian in reaching such a judgment? ... Hence it is my contention that a positive judgment that a miracle has taken place is always a philosophical or theological judgment.

(Meier 1994:513-514; cf. 521. See also Allison 2005:350-351 and Wedderburn 1999:96)1

Meier goes on to explain that after a historian has completed an exhaustive investigation of a possible miraculous event, he may affirm that no reasonable natural cause is known, that the event took place in a context charged with religious significance and that some witnesses claimed, even believed, that it was a miracle. However, his job ends there in his capacity as historian (Meier 1994:513, cf. Dunn 2003:875; Evans 2006:139; Johnson 1996:136; Tilley 2003:14).

[T]o move beyond such affirmations and to reach the conclusion that God indeed has directly caused this inexplicable event is to cross the line separating the historian from the philosopher or theologian

(Meier 1994:514).

Similar statements have been made pertaining specifically to Jesus' resurrection (Carnley 1987:89; Ehrman's opening statements in Ehrman \& Licona 2008 and Ehrman \& Licona 2009; Theissen \& Winter 2002:250). Since the worldviews of historians play such a prominent role in adjudicating on the historicity of Jesus' resurrection, Allison contends that historians find themselves in a stalemate and must punt to philosophers and theologians (Allison 2005:339-340, 351). However, it does not prevent him from trying (199 n2; Dunn 2003:878; McCullagh 1984:28; Wedderburn 1999:96). Therefore, we have two separate arguments: Historians cannot say that 'God performed x' since they have no way of verifying it and the judgement that a miracle occurred requires a theistic worldview that is in conflict with the worldviews of other historians. Therefore, the matter must be placed in the hands of philosophers and theologians. Let us look carefully at each of these arguments.

\section{Historians cannot conclude that God did it, since they have no access to such} knowledge

While I am sympathetic to Meier's contention that God is outside of the purview of historians, historians

Meier does not classify the resurrection of Jesus as a miracle because it does not fit his definition of miracle (1994:529). The first component of his definition is that 'a miracle involves an event that is in principle perceivable by all interested and fair-minded observers' (1994:512). Since Jesus' post-mortem appearances were not afforded to everyone according to Acts 10:40-41, it does not meet his criteria for a miracle. However, this is an odd component for any definition of miracle, since the difference consists in the audience rather than the act. Moreover, Meier does not seem to exclude a resurrection in general from being a miracle; only Jesus' resurrection as reported in Acts 10. It should be noted that defining 'miracle' and providing criteria for identifying one are separate discussions. 
do not need direct access to the explanatory entities in their hypotheses. Scientists often posit theoretical entities to which they have no direct access, such as quarks, strings, gluons and black holes (comments by Craig in Craig \& Ehrman 2006:24; Lorenz 1994:312; Tucker 2004:4; Wright 2003:15-16; Zammito 2005:178, cf. 177). All of these are postulated as inferences from the evidence.

Templeton laureate John Polkinghorne states that as a theoretical physicist he believes that protons and neutrons consist of subatomic particles (e.g. quarks and gluons) although these never have been and probably never will be seen. He asserts that he believes in the occurrences of the Big Bang and biological evolution even though he was not there to witness either. $\mathrm{He}$ believes because of phenomena consistent with these being true. He also believes Jesus' resurrection for the same reason: The extant historical data is most consistent with Jesus' resurrection (Polkinghorne 2005:116-118)

If scientists can posit theoretical entities as inferences from the evidence, so can historians. Historians do not have direct access to any of the objects of their study, since the past is forever gone (comments by Craig in Craig \& Ehrman 2006:9). Historians only have remnants from the past and they infer past entities and events on the basis of the evidence that has come to them. Dunn writes:

In one sense, of course, we are simply recognizing the nature of the evidence which any biographer has to weigh who has no access to any writings of the biography's subject. That is to say, a portrayal of Jesus as seen through the eyes and heard through the ears of his first disciples is neither an illegitimate nor an impossible task, and such a portrayal, carefully drawn in terms of the evidence available, should not be dismissed or disparaged as inadmissible.

(Dunn 2003:131)

Moreover, the theological objection only disputes the cause of a miraculous event rather than the event itself. Historians often must leave the cause of an event unanswered. Yet this does not prohibit them from drawing certain historical conclusions. Historians are certain that Carloman died in AD 771, although they are uncertain whether his brother Charlemagne had him murdered or whether he died of natural causes. In this case, historians need not hesitate to conclude that Carloman died in AD 771 while leaving a question mark pertaining to the cause of his death. In a similar way, historians could conclude that Jesus rose from the dead without deciding on a cause for the event. They can answer the what (i.e. what happened) without answering the how (i.e. how it happened) or why (i.e. why it happened). After all, it is only the theological implications of the historical conclusion that give pause.

This approach allows historians to investigate what is unquestionably the historical portion of miracle claims (Habermas 2003:4; cf. Habermas 2007:288; Craig 1989:419). It would be too much to argue on historical grounds that Jesus had a 'resurrection' body as understood by first-century Christians, since that understanding was accompanied by numerous theological implications, such as that Jesus' resurrection was believed to have been the first fruits of the general resurrection that will occur on the last day when God will make everything right, redeem the righteous and condemn the wicked. The fullness of resurrection theology cannot be verified by historical investigation (Eddy \& Boyd 2007:88-89; Moltmann 1996:80; Peters 2006:149-169).

Alan Segal may be correct in asserting that there is insufficient historical evidence to conclude that 'Jesus was actually and physically raised from the dead and that he appeared in his transformed fleshly body' (Segal 2006:136). However, if we nuance this statement by adding four words, I see no reason why the historian in theory is blocked from concluding, 'Jesus was actually and physically raised from the dead and he appeared in what others interpreted as his transformed fleshly body.' If I am correct, Schmidt punts prematurely when writing:
The events which the gospel messages recount in connection with the Resurrection cannot be brought within our horizon of empirical confirmation and historic understanding. . . One has a strong impression that the only thing that would fall under the authority of historical investigation is the presence of the Resurrection doctrine in the kerygma of the original Church. About the 'facts' one must question whether they - be they unhistorical, trans-historical, or meta-historical - simply fall out of our reach (and thereby become, as facts, irrelevant).

(Schmidt 1984:78)

It may likewise be observed that if the evidence for a miracle such as the resurrection of Jesus occurs in a context that is charged with religious significance, the resurrection hypothesis could be the strongest explanation for the beliefs of the disciples and Paul that Jesus had been raised from the dead and had appeared to them. Meier's position at best mitigates against historians identifying the cause of Jesus' return to life or the precise nature of Jesus' revivified body, but it should not deter historians from adjudicating on the event itself. Lüdemann writes:

Indeed, the miraculous or revelatory aspect of Jesus cannot be the object of any scientific approach. However, as long as theology is 'paired' with historical thought (as it is on the one hand by the character of its central sources and on the other by modern criteria of truth), then it must be interested in a natural explanation of the miracle - or it must admit that even on historical grounds a supernatural explanation is more plausible.

(Lüdemann 2004:21. See also Craffert 2003:347)

Ehrman's objection is nuanced. He asserts that the entire exercise of ascertaining whether Jesus rose from the dead is illegitimate for historians because it implies that God did it. This objection confuses historical conclusions with their theological implications. He is doing history backwards. Historians should approach the data neither presupposing nor a priori excluding the possibility of God's acting in raising Jesus. They should then form and weigh hypotheses for the best explanation for that data from a position of openness. Probability ought to be determined in this manner rather than by forming a definition of 'miracle' that excludes the serious consideration of a hypothesis prior to an examination of the data. Moreover, as suggested above historians often must leave the cause of an event unanswered although this does not deter them from drawing historical conclusions.

\section{Since worldview plays a major part in the adjudication of miracle claims, historians must leave the matter in the hands of philosophers and theologians}

Historical descriptions are almost always heavily influenced by the historian's race, gender, nationality, values, political and religious convictions, concepts of the external world and of the nature of history itself. More often than not, the result is pluralism even in nonreligious matters. A Marxist approach to history, which attempts to explain the past as the result of social movements of working classes rather than rulers, will usually yield historical narratives in conflict with those generated by other approaches. Yet, historians do not suggest that they cannot write histories of the American Revolution or the Vietnam War since a degree of incommensurableness presents itself when Marxist descriptions differ from those provided by non-Marxist historians.

It is both common and necessary for historians, philosophers and theologians to cross disciplines. Historians neglecting to do this may unwittingly produce poor results (Barrera 2001:205; Evans 1999:10; Fischhoff 1982:350; Gilderhus 2007:111-112; Harvey 1996:55-56; Lorenz 1994:298, cf. 312; McIntyre 2001:7; 14; Shaw 2001:9; Vann 2004 3). Philosopher of history J.H. Hexter notes the lack of dialogue between philosophers and historians with the result that some historians have 'a rather special gift for leaping aboard intellectually sinking ships and drawing their innocent followers along with them' (Hexter 1971:110). Miller contends 
that even if a New Testament scene is implausible, 'no one can deny its possibility.' In a note, he adds:

The issue is relevant in regards to miracles. Since judgments about their possibility are cosmological and not historical, they force biblical scholars to moonlight as philosophers of science, with predictably messy results (though we seem as untroubled by it as do philosophers and theologians who cite biblical texts uncritically). We have much to learn from the philosophy of science and the philosophy of religion on the cosmological and theological issues entailed in judgments about the possibility of miracles. One problem, which cannot be cavalierly dismissed, is that the cosmological assumptions routinely made in our guild are beholden in part to an obsolete nineteenth-century worldview.

(Miller 1992:17, n17; cf. Stewart 2006:3).

Philosopher Eleonore Stump similarly comments that:

philosophers and historians need to talk to each other (philosophers and historians and literary theorists, we might add), and that these groups have a great deal to learn from each other" (Stump 1989:371). This is especially necessary when it is noted that the "strong similarities" between the disciplines of history and theology allow them to have "a remarkably fruitful marriage in biblical scholarship.

(McIntyre 2001:2. See also Barclay 1996:28)

Broad examples where the marriage of disciplines occurs are readily at hand. Archaeologists are significantly assisted in piecing together a detailed history of their sites through a study of the ancient texts describing them. When a biblical scholar studies the pathological effects of scourging and crucifixion from medical professionals in order to gain insights into Jesus' death, it is doubtful he or she would be accused of stepping outside of his or her capacity as a historian. Philosophers of science must have an understanding of the principles of science.

Professional historians also cross disciplines. Philosopher of history J.L. Gorman speaks of debates among historians concerning whether the meaning of historical truth is a matter for historians or philosophers (Gorman 2000:253). Rex Martin, another philosopher of history, comments that historians always 'make philosophical presuppositions' when writing their books and adds that 'historians need philosophy to do their work as historians better' (Martin 2006:253,260). In fact, historians always make numerous philosophical assumptions before entering every historical investigation. For example, they assume the external world is real. They assume our senses provide a fairly accurate perception of the external world. They assume logic facilitates us in our quest for truth rather than merely being a pragmatic tool aimed at our survival and quality of life. They assume natural laws in effect today were in effect in antiquity and that they operated in a similar manner. More importantly, the majority of historians assume that history is at least partially knowable (McCullagh 1984:1). Whereas the vast majority of all historians agree on most of these assumptions, a number of postmodernists take issue with some of them, especially the last. For these, not only is a historical judgement on miracle claims out of the question, so is a judgement on every other past event. Yet, this does not keep realist historians from making historical judgements. Each of the five assumptions just mentioned is purely philosophical in nature. While good reasons exist for holding a realist view of history over a postmodern approach, at the end of the day, realist and postmodernist positions are based on assumptions that cannot be defended to a point beyond all doubt. McCullagh admits:

[The truth of the] assumptions [behind realism] cannot be proved, as philosophers have been tireless in explaining. We have no access to reality independent of our beliefs and experiences of it, so we cannot check in a God-like manner upon their truth. We are justified in holding them because it is useful to do so; indeed we may even be psychologically incapable of doing otherwise.

(McCullagh 1984:1)
Why then are philosophical considerations off-limits to a historian? No reason exists a priori for philosophical matters to be restricted to professional philosophers. It is an artificial boundary. This becomes especially clear when we consider that some biblical scholars may also have training in philosophy while some philosophers may also be trained in historiography. Although Dale Allison and Gary Habermas are friends, I doubt that Allison would be content if the following dialogue had to take place:

Allison: My training and work have been in the fields of biblical historiography and exegesis. Accordingly, since Jesus' resurrection requires God's existence, I do not believe I am qualified to adjudicate on the historicity of the event. I must punt to the philosopher. Habermas: My training and work have been in the fields of the philosophy of religion and historiography. Since adjudicating on Jesus' resurrection requires both, I am qualified to render a judgement pertaining to the historicity of the event. Consequently, only those with formal training and work in both disciplines may adjudicate on the historicity of Jesus' resurrection and those who are trained only as biblical scholars should henceforth be silent on the matter.

\section{LACK OF CONSENSUS}

A few scholars argue that historians can never conclude that a particular miracle has occurred because a consensus is required for awarding historicity and such a consensus eludes us in respect of miracle claims. Alan Segal writes: A historical theory should be available to assent or dissent regardless of one's religious perspective. And that is a truer and more accurate statement of the consensus.

(Segal 2006:136)

Ehrman argues in a similar manner: '[T]he theory behind the canons in historical research is that people of every persuasion can look at the evidence and draw the same conclusions' (comment by Ehrman in Craig \& Ehrman 2006:25. See also Henaut 1986:188).

I suggest that it is unreasonable to require a consensus before awarding historicity because the horizons of historians often prevent such consensus even in nonreligious matters. This is because the horizon of the historian will certainly impact his or her conclusions. Although this challenge is ever present in historical Jesus studies, it is not unique to it, since it is likewise present in historical inquiries involving matters of race, gender, ethics, nationality and politics. This is readily acknowledged by historians outside of the community of biblical scholars. Philosopher of History Richard Evans writes:

We know of course that we will be guided in selecting materials for the stories we tell, and in the way we put these materials together and interpret them, by literary methods, by social science theories, by moral and political beliefs, by an aesthetic sense, even by our own unconscious assumptions and desires. It is an illusion to believe otherwise.

(Evans 1999:217)

Fischhoff similarly opines, 'Inevitably, we are all captives of our present personal perspective. . . There is no proven antidote' (Fischhoff 1982:349). McCullagh writes:

I conclude that the cultural bias now being discussed, which does not involve false or misleading descriptions of the past, is inescapable and provides the main reason for saying that history is subjective. In this way I agree that history is subjective.

(McCullagh 1998:35)

Evans, Fischhoff and McCullagh are not biblical scholars but they recognise the challenge posed by one's horizon in any historical investigation. Supporting data may be observed in A Statistical Summary of Survey Results in The Practice of American History: A Special Issue of The Journal of American History (1994). Of particular interest is the response of historians to the question of 'allegiances or identities as important to them as historians'. The leading answer was 'Ideological commitments' (41\%), followed 
by 'Education' (38.7\%) and then 'Nationality' (31.3\%). 'Religion' $(14.8 \%)$ placed seventh as an allegiance (1193).

Consider the following statements by two more historians, neither of whom are biblical scholars. Gilderhus comments:

The body of literature on almost any historical subject takes the form of an ongoing debate.... By the very nature of the subject, history tends to divide scholars and set them at odds. ... We no longer possess a past commonly agreed upon. Indeed, to the contrary, we have a multiplicity of versions competing for attention and emphasizing alternatively elites and nonelites, men and women, whites and persons of color, and no good way of reconciling all the differences. Though the disparities and incoherencies create terrible predicaments for historians who prize orderliness in their stories, such conditions also aptly express the confusions of the world and the experiences of different people in it.

(Gilderhus 2007:86, 113)

Lorenz contends that a proper philosophy of history:

must elucidate the fact that historians present reconstructions of a past reality on the basis of factual research and discuss the adequacy of these reconstructions; at the same time it must elucidate the fact that these discussions seldom lead to a consensus and that therefore pluralism is a basic characteristic of history as a discipline.

(Lorenz 1994:326. See also Gilderhus 2007:85, 93)

Therefore, I think Craffert is mistaken when he asserts that 'no one has the right to use the tag historical unless it can win the respect of fellow historians' (Craffert 1989:341-343). If historians outside of the community of biblical scholars are within their professional rights in drawing conclusions on nonreligious matters in the absence of consensus, why do some biblical scholars suggest that consensus is required when horizons have an even greater influence in religious matters?

Indeed, Ehrman is inconsistent in his application of his own rule. Since the Qur'an states that Jesus was not killed in the first century (Q 4:157-158), Muslim historians deny Jesus' execution by Pilate and instead believe that God spared him from death, despite very strong evidence to the contrary. Moreover, a handful of scholars on the periphery question whether the historical Jesus even existed, let alone whether he was crucified or not. And yet, the lack of consensus does not deter Ehrman from concluding that Jesus died by crucifixion (Ehrman 2000:162; 2008:235, 261-262). When the worldviews or hypercritical approaches of particular historians get in the way of their practice, more sober-minded historians are not thwarted from arriving at firm conclusions. Habermas contends:

[S]ince when is convincing a person of the opposite persuasion a prerequisite for arguing that one's view is fairly indicated by the data? Is it not the case that the opposite could also be said with assurance? How likely is it that the argument constructed by a skeptic or agnostic would convince a believer against his/her position? I doubt that either side wants this to be a prerequisite for their rationality!

(Habermas 2007:286)

Given the prominent role of the horizons of historians in every historical inquiry, we can anticipate that consensus opinions will often elude historians as a result of 'interpretive polarities' (Martin 1998:28). Philosopher of history Peter Novick states that it is 'impossible to locate' a 'scholarly consensus . . . to sustain objectivity' (Novick 1988:572) while Anchor, another philosopher of history, warns that 'there are many, sometimes incompatible, interpretations of the same events' and 'there is no guarantee of consensus in history' (Anchor 1999:113).

Unfortunately, rather than an objective and careful weighing of the data, the subjective horizons of historians, especially those of historians writing on religious, philosophical, political and moral topics, exert great influence in their final judgements (Denton 2004:89). Moreover, many members of the audience to whom historians present their research are no less biased. Accordingly, what is judged as sound and persuasive research to one group may be viewed as inadequate and overly biased by another. Anchor writes:

As there are always alternative ways to interpret the traces of the past (our evidence), an essential part of the historian's task is to figure out which among them is best, that is, which among them is most likely to be true." Which explanation seems "most plausible" varies not only with the cognitive expectations but also with the normative expectations of the audiences that are being addressed.

(Anchor 1999:114; cf. Swinburne 2003:3)

I have engaged in a number of public debates on the question of the historicity of Jesus' resurrection. In 2008 I debated with Bart Ehrman, a biblical scholar whom I respect. We enjoyed a debate where we exchanged ideas and offered criticisms of the other's view in a collegial manner. A number of Christians present approached me afterwards and told me they believed I clearly won the debate. However, I know of two others who had attended and who commented that I clearly had lost. The horizons of some audience members impacted their ability to judge the debate.

The election for president of the United States recently took place. A number of televised debates between the final candidates took place and it was very interesting to hear the comments of the political pundits following the debates. Liberals and conservatives alike declared clear victories for their candidates and none were willing to acknowledge valid points made by the candidate representing the opposing party. It is certain that many were placing a 'spin' on the results in order to promote their view. However, it is likewise certain that pundits on both sides sincerely believed that their candidate won the debate. Our horizons impact our objectivity far more than most of us realise or acknowledge. A consensus can be reached as a result of shared biases, convictions, objectives and a lack of knowledge. We need to be reminded every so often that a consensus of scholars does not establish the objectivity or truth of their conclusion. Communities in the past have held numerous beliefs that have since been disproved (Evans 1999:99; Tucker 2004:2425). Crossan seems wise when writing, 'I think it's the job of a scholar to take on the majority every now and then' (comments by Crossan in Copan 1998:46).

It is highly unlikely that a consensus will ever exist pertaining to the historicity of a miracle claim such as the resurrection of Jesus. While strong agreement exists regarding a number of 'facts' often used as evidence to support the resurrection hypothesis, no consensus will ever exist for the conclusion that the resurrection hypothesis is an accurate description of what actually occurred. After all, how likely is it that historians who are Muslims and atheists will confess that the resurrection hypothesis is the best explanation or that Christian historians will confess that the resurrection hypothesis is not the best explanation? Yet, either Jesus rose from the dead or he did not; and historians holding one of these positions are more correct than those not holding it.

\section{Accordingly, $\mathrm{O}^{\prime}$ Collins is mistaken when writing:}

If the (historical) evidence were sufficient to establish or conclusively confirm resurrection belief, such belief should be utterly convincing to all those willing to weigh the evidence and draw the obvious conclusion from it. Yet this would be a return to Pannenberg's position ... and to its obvious rebuttal. If Pannenberg is correct, those best able to evaluate the evidence (i.e. historians) should be much more prominent among the ranks of those who agree with the conclusion that Jesus was raised from the dead.

(O'Collins 2003:49-50)

Because of the influence of horizons, many historical descriptions will never receive a stamp of approval from the consensus of the relevant scholars. However, this should not restrain the historian from stating that his or her hypothesis is probably true. Meyer wrote:

The reason why we feel vulnerable is that we cannot easily avail ourselves of a knock-down proof that everyone will accept. This 
honest reflection, however, overlooks the fact and issue of horizon. We should not expect that hermeneutical questions are resolvable in the sense that all will catch on and agree, and only the flatearthers be at a loss.

(Meyer 1994:133-134)

\section{MIRACLE CLAIMS IN MULTIPLE RELIGIONS}

Hume contended that testimonies of miracles in one religion are weighed against an infinite number of witnesses who testify of miracle claims in other religions. Therefore, these cancel out each other (Hume 2000 (1777): 127). Ehrman argues that if we accept that Jesus performed miracles, we must also 'be willing in principle to concede that other people did them as well' (Ehrman 2008:242; comments by Ehrman in Craig \& Ehrman 2006:22. See also Craffert 1989:342; Lindars 1986:91; Segal 2006:136). He provides as examples Muhammad, Apollonius of Tyana, Honi the CircleDrawer, Hanina ben Dosa, and the Roman Emperor Vespasian. "The evidence that is admitted in any one of these cases must be admitted in the others as well" (Ehrman 2008:242, 269. See also Segal 2006:136 who provides as examples the miraculous giving of the Quran to Muhammad' and the six-day creation). For Ehrman, we reject them because they do not agree with our particular religious or philosophical beliefs (comments by Ehrman in Craig \& Ehrman 2006:33-34).

Must miracle claims in multiple religions cancel each other out as Hume claimed? This holds neither in other historical inquiries nor in science. When origin hypotheses of naturalistic and theistic evolution are proposed, we can know immediately that both cannot be ontologically true. But I do not think one is warranted in asserting that they cancel one another out as viable descriptions of the origin of life or from further consideration.

I agree with Ehrman that if we admit the evidence for the miracles of Jesus we must likewise admit whatever evidence there might be for miracles in non-Christian religions and be open to nonChristian figures performing miracles. Since the majority of scholars agree that the historical Jesus performed acts that he and others viewed as exorcisms and miracles, evidence for miracles in non-Christian religions must be admitted into consideration (Licona 2009). But this does not mean that the evidence is equal in quality.

Poorly attested miracle claims are scarcely able to rule out wellevidenced ones. We may agree with Hume that most miracle claims are poorly attested. Most miracle reports appear centuries after the purported events and are not usually corroborated by multiple sources or neutral-to-hostile witnesses. However, Hume and Ehrman fail to recognise that the reports of Jesus' miracles are far superior in quality than what is extant for other miracle claims.

This becomes clear when comparing the examples provided by Ehrman. Reports of miracles performed by Muhammad are absent in the Qur'an and do not appear until much later. Philostratus's biography of Apollonius was written c. AD 225, approximately 125 years after the death of Apollonius compared to the evangelists writing within 35 to 70 years of Jesus' death. Moreover, we have very few extant sources from antiquity outside of Philostratus that refer to Apollonius and those sources tell us precious little (Lucian, 'Alexander the False Prophet' 5; Origen, Contra Celsum 6.41.5-10).

Onias, also known as Honi the Circle-Drawer, is first mentioned in Josephus as one whose prayers for rain were answered (Jos Ant 14:22). Around three centuries after Josephus, the story is reported in the Jerusalem Talmud with many more details. Honi prays for rain. When it does not come, he draws a circle and stands inside it, promising not to leave his spot until it rained. When only a few drops came, Honi said this is not what he had prayed for. Then it rained violently. But Honi said he had prayed for 'rain of good will, blessing, and graciousness'. Then it rained in a normal manner (Y. Taanit 3:8-9 66d, in Neusner 1987:226).
It may be observed that, while Josephus places Honi in the first century BC, the Jerusalem Talmud places him in the sixth century BC, 500 years earlier. Moreover, Josephus's account is approximately 150 years after the purported event (assuming the closer date), further removed from the event it reports than the evangelists are from theirs.

Hanina ben Dosa is a first-century AD figure who is likewise mentioned in the Mishnah (c. AD 200; TB Berarkhot 34b; 61b; Yevamot 21b; TB Sotah 9:15; TB Baba Batra 74b; TB Ta'anit 24; 25a) and appears in the Talmud (AD 400-600; Neusner 2005:53; c. AD 400 for the Jerusalem Talmud and by AD 600 for the Babylonian Talmud). Therefore, the first report on Hanina ben Dosa's miracles as with Honi is about 150 years after the purported events, again, much later than the 35 to 45 years we find with the miracles of Jesus reported in Mark's Gospel.

Three sources report two miracles performed by the Roman Emperor Vespasian. Tacitus and Suetonius write around 35 years after the purported event (Annals 4.81; Twelve Caesars, Vespasian 7.2), while Dio Cassius reports it at least 110 years later (65.8.1). Two of the three sources wrote as close to the event as Mark was to Jesus. It appears likely that Apollonius performed a few miracles, since some are reported by Philostratus (3.38$40 ; 4.45 ; 6.43)$ and Origen noted that Moiregenes had referred to Apollonius as a 'magician and philosopher' (magou kai philosophos), that he had 'magical power' (magaios) and was a 'swindler/imposter' (goēta) (Contra Celsum 6.41.5-10).

Whereas several plausible explanations exist for most miracle claims, this may not be the case for others. We may not be assured that Honi and Hanina actually performed deeds regarded as miracles by witnesses. However, there is wide scholarly agreement that Jesus performed deeds that both he and others regarded as exorcisms and miracles (Licona 2009). And there is evidence that Apollonius and Vespasian performed miracles; however, we may interpret what actually occurred. My objective here is not to argue that a miracle hypothesis is more plausible than a naturalistic theory posited for the reports of Jesus' miracles. Instead, I have attempted to demonstrate that historians who regard the miracles of Jesus as historical need not acknowledge the historicity of the miracles from other religions given the disparity of evidence between them. Miracle reports should be examined on a case-by-case basis (Crossley 2005:181). If it turns out that there are good reasons for holding to the historicity of a particular miracle claim, there is no a priori reason for withholding a positive verdict from it because poorly evidenced miracle claims exist.

I wish to make one further comment pertaining to Ehrman's contention. He asserts that Christians reject miracle claims in other religions because they do not agree with their particular religious or philosophical beliefs (comments by Ehrman in Craig \& Ehrman 2006:33-34). This argument commits the genetic fallacy. It is certain that Christians, those of other faiths, agnostics and atheists often hold certain beliefs and reject others for poor reasons. But this does not warrant the conclusion that those beliefs are mistaken. A Christian may believe that Jesus of Nazareth performed deeds he and others believed were miracles because it is reported in a text he believes is inspired by God. Although this would be a poor reason for a historian to arrive at the conclusion that Jesus was a miracle worker, it does not warrant the conclusion that historians cannot weigh the data and arrive at the same conclusion as those who get there by other means.

\section{CONCLUSIONS}

In this article I have examined three common objections to the investigation of miracle claims by historians: the theological objection, lack of consensus and miracle claims in multiple religions. I argued that all three can be rather easily answered. When combined with the contentions in my previous article, namely, the positive case I presented that historians are within 
their professional rights in investigating miracle claims and the failure of two additional objections to this contention, I am suggesting that a paradigm shift should occur within the community of biblical scholars and that those historians investigating miracle claims are within their professional rights in doing so.

\section{REFERENCES}

Allison, D.C., 2005, Resurrecting Jesus: The earliest Christian tradition and its interpreters, T \& T Clark, New York.

Anchor, R., 1999, 'The quarrel between historians and postmodernists', History and Theory 2(38), 111-121.

Barclay, J.M.G., 1996, 'The resurrection in contemporary New Testament scholarship', in D'Costa (ed.), Resurrection reconsidered, pp. 13-30, Oneworld, Oxford.

Barrera, J.C.B., 2001, 'Making history, talking about history', History and Theory 5(40), 190-205.

Carnley, P., 1987, The structure of resurrection belief, Oxford University Press, New York.

Copan, P. (ed.), 1998, Will the real Jesus please stand up?, Baker, Grand Rapids.

Craffert, P.F., 1989, 'The origins of resurrection faith: The challenge of a social scientific approach', Neotestamentica 2(23), 331-348.

Craffert, P.F., 2003, 'Mapping current South African Jesus research: The Schweitzerstrasse, the Wredebahn and cultural bundubashing', Religion and Theology 10(3/4), 339377.

Craig, W.L., 1989, Assessing the New Testament evidence for the historicity of the resurrection of Jesus, Edwin Mellen Press, New York.

Craig, W.L. \& Ehrman, B.D., 2006, 'Is there historical evidence for the resurrection of Jesus? A debate between William Lane Craig and Bart D. Ehrman', viewed 29 April 2009, from http://www.holycross.edu/departments/crec/website/ resurrection-debate-transcript.pdf.

Crossley, J.G., 2005, 'Against the historical plausibility of the empty tomb story and the bodily resurrection of Jesus: A response to N.T. Wright', Journal for the Study of the Historical Jesus 6, 171-186.

Denton, Jr, D.L., 2004, Historiography and hermeneutics in Jesus studies: An examination of the work of John Dominic Crossan and Ben F Meyer, T \& T Clark International, London.

Dunn, J.D.G., 2003, Jesus remembered, Eerdmans, Grand Rapids.

Eddy, P.R. \& Boyd, G.A., 2007, The Jesus legend: A case for the historical reliability of the synoptic Jesus tradition, Baker Academic, Grand Rapids.

Ehrman, B.D., 2000, The historical Jesus: Lecture transcript and course guidebook, vol. 2, The Teaching Company, Chantilly.

Ehrman, B.D., 2008, The New Testament: A historical introduction to the early Christian writings, 4th edn., Oxford University Press, New York.

Ehrman, B.D. \& Licona, M.R., 2008, Can historians prove that Jesus rose from the dead?, 2 DVDs, Midwestern Baptist Theological Seminary, Kansas City.

Ehrman, B.D. \& Licona, M.R., 2009, Can historians prove that Jesus rose from the dead?, 2 DVDs, Southern Evangelical Seminary, Charlotte.

Evans, C.A., 2006, Fabricating Jesus: How modern scholars distort the gospels, IVP, Downers Grove.

Evans, R.J., 1999, In defense of history, WW Norton, New York.

Fischhoff, B., 1982, 'For those condemned to study the past: Heuristics and biases in hindsight', in D. Kahneman, P. Slovic and A. Tversky (eds.), Judgment under uncertainty: Heuristics and biases, pp. 335-351, Cambridge University Press, New York.

Geisler, N.L. \& Meister, C.V. (eds.), 2007, Reasons for faith: Making a case for the Christian faith, Crossway, Wheaton.

Gilderhus, Mark T., 2007, History and historians: A historiographical introduction, 6th edn., Prentice Hall, Upper Saddle River.

Gorman, J.L., 2000, 'Freedom and history', History and Theory $39(5), 251-262$
Habermas, G.R., 2003, The risen Jesus and future hope, Rowman and Littlefield, Lanham.

Habermas, G.R., 2007, 'The resurrection of Jesus and recent agnosticism' in N.L. Geisler \& C.V. Meister (eds.), Reasons for faith: Making a case for the Christian faith, pp. 281-294, Crossway, Wheaton.

Harvey, V.A., 1996, The historian and the believer: The morality of historical knowledge and Christian belief, University of Illinois, Urbana.

Henaut, B.W., 1986, 'Empty tomb or empty argument: A failure of nerve in recent studies of Mark 16?', Science religieuses/ studies in religion 2(15), 177-190.

Hexter, J.H., 1971, The history primer, Basic Books, New York.

Hume, D., 1777 (2000), 'Essays and treatises on several subjects, vol. 2, An enquiry concerning human understanding', viewed 17 June 2008, from http://www.etext.leeds.ac.uk/ hume/ehu/index-div2-N966696959.

Johnson, L.T., 1996, The real Jesus: The misguided quest for the historical Jesus and the truth of the traditional gospels, Harper San Francisco, San Francisco.

Licona, M., 2009, 'Historians and miracles: The principle of analogy and antecedent probability reconsidered', HTS Teologiese/Theological Studies 65(1), 56-61.

Lindars, B., 1986, 'Jesus risen: Bodily resurrection but no empty tomb', Theology 89, 90-96.

Lorenz, C., 1994, 'Historical knowledge and historical reality: A plea for internal realism', History and Theory 10(33), 297-327.

Lüdemann, G., 2004, The resurrection of Christ: A historical inquiry, Prometheus, Amherst.

Martin, R., 1998, 'Progress in historical studies', History and Theory 2(37), 14-39.

Martin, R., 2006, 'Do historians need philosophy?' History and Theory 5(45), 252-260.

McCullagh, C.B., 1984, Justifying historical descriptions, Cambridge University Press, Melbourne.

McCullagh, C.B., 1998, The truth of history, Routledge, New York.

McIntyre, J., 2001, 'The uses of history in theology', Studies in World Christianity 1(7), 1-20.

Meier, J.P., 1994, A marginal Jew: Rethinking the historical Jesus, vol. 2, Mentor, message, and miracles, Doubleday, New York.

Meyer, B.F., 1994, Reality and illusion in New Testament scholarship, The Liturgical Press, Collegeville.

Miller, R.J., 1992, 'Historical method and the deeds of Jesus: The test case of the temple demonstration', Foundations and Facets Forum 8(102), 5-30.

Neusner, J. (ed.), 1987, The Talmud of the land of Israel: A preliminary translation and explanation, vol. 18, University of Chicago Press, Chicago.

Novick, P., 1988, That noble dream: The 'objectivity question' and the American historical profession, Cambridge University Press, New York

O'Collins, G., 2003, Easter faith: Believing in the risen Jesus, Paulist, New York.

Philostratus, F. (n.d.), Apollonius of Tyana, Books $I-V, V-V I I I$, transl. C.P. Jones, Harvard University Press, Cambridge, MA.

Polkinghorne, J., 2005, Quarks, chaos and Christianity: Questions to science and religion, 2nd edn., Crossroad, New York.

Schmidt, P., 1984, 'The interpretation of the Resurrection: Historical and theological truth', International Catholic Review/Communio 1(11), 75-88.

Segal, A., 2006, 'The resurrection: Faith or history?' in R.B. Stewart (ed.), The resurrection of Jesus: John Dominic Crossan and N.T. Wright in dialogue, pp. 121-138, Fortress, Minneapolis.

Shaw, D.G. 2001. 'Happy in our chains? Agency and language in the postmodern age', History and Theory 12(40), 1-9.

Stewart, R.B. (ed.), 2006, The resurrection of Jesus: John Dominic Crossan and N.T. Wright in dialogue, Fortress Press, Minneapolis.

Stump, E., 1989, 'Visits to the sepulcher and Biblical exegesis', Faith and Philosophy 6/4(10), 353-377. 
Swinburne, R., 2003, The resurrection of God incarnate, Oxford University Press, New York.

Theissen, G. \& Winter, D., 2002, The quest for the plausible Jesus: The question for criteria, Westminster John Knox, Louisville.

Tilley, T.W., 2003, 'More than a Kodak moment: What to look for in the Resurrection', Commonweal 7(130), 13-16.

The Journal of American History, 1994, The practice of American history: A special issue. A statistical summary of survey results, Organization of American Historians, Bloomington.

Tucker, A., 2004, Our knowledge of the past: A philosophy of historiography, Cambridge University Press, New York.
Vann, R.T., 2004, 'Historians and moral evaluations', History and Theory 12(43), 3-30.

Wedderburn, A.J.M., 1999, Beyond resurrection, Hendrickson, Peabody.

Wenham, D. \& Blomberg, C., 2003, Gospel perspectives, vol. 6, The miracles of Jesus, Wipf and Stock, Eugene.

Wright, N.T., 2003, The resurrection of the Son of God, Fortress, Minneapolis.

Zammito, J., 2005, 'Ankersmit and historical representation', History and Theory 5(44), 155-181. 